\title{
Nutrient intake by kindergarten children in Beijing and Xian, China in 2004-2005, with special reference to sources of high sodium intake
} \author{
Shinichiro Shimbo ${ }^{7}$ and Masayuki Ikeda ${ }^{8 *}$ \\ ${ }^{1}$ School of Nursing, Miyagi University, Taiwa-cho 981-3298, Japan \\ ${ }^{2}$ Department of Childhood Education, Faculty of Human Sciences, Tohoku Bunkyo University, Yamagata 990-2316, Japan \\ ${ }^{3}$ National Natural Science Foundation of China, Beijing 100085, China \\ ${ }^{4}$ Department of Social Medicine and Health Education, School of Public Health, Peking University, Beijing 100191, China \\ ${ }^{5}$ Physical Education College, Jilin University, Changchun 130012, China \\ ${ }^{6}$ Shokei Gakuin University, Miyagi 981-1295, Japan \\ ${ }^{7}$ Kyoto Women's University, Kyoto 605-8501, Japan \\ ${ }^{8}$ Kyoto Industrial Health Association, Kyoto 604-8472, Japan
}

Haruo Nakatsuka ${ }^{1}$, Takao Watanabe ${ }^{2}$, Zuowen Zhang ${ }^{3}$, Peiyu Wang ${ }^{4}$, Aiping Liu ${ }^{4}$, Baohua Liu ${ }^{4}$, Zhongmin Liu $^{5}$, Kozue Yaginuma-Sakurai $^{6}$

\begin{abstract}
Background and objectives: China has been experiencing dramatic social changes in recent years. From nutritional view, nutrient intakes of children should be clarified as baseline data at the early stage of the change. Food intake records were available to this study group for this purpose.

Methods: In practice, 120 children (60 boys and 60 girls) were studied, who were at the ages of 5 to 6 years attending kindergartens in Beijing (in 2004 and 2005 ) and Xian (in 2005). Guardians provided informed consents on behalf of children and submitted 24-hour duplicates of foods and drinks at the amounts served to children.

Results: Children took $1373 \mathrm{kcal}$ energy, $59.6 \mathrm{~g}$ protein, $39.8 \mathrm{~g}$ lipid and $204.2 \mathrm{~g}$ carbohydrate per day. Cereals accounted for $39.1 \%$ of energy and 23.3\% of protein. When compared with nationally set AI (adequate intake) or RNI (recommended nutrient intake), energy and macro-nutrient intakes were barely sufficient. Vitamin $\mathrm{A}$ and vitamin $\mathrm{C}$ intakes were quite sufficient, whereas thiamin intake was only barely so. Intake of $\mathrm{Na}$ was as high as more than twice AI. The Na intake was confirmed also by instrumental analysis. A close association of high $\mathrm{Na}$ intake with wheat-based foods was detected. Consumption of fast foods was quite limited.

Conclusions: Intakes were adequate for energy and macro-nutrients already early in this century, but improvements were necessary for several micro-nutrients. Na intake was especially quite in excess; an association with wheat-based foods was detected. Food contamination with $\mathrm{Cd}$ or $\mathrm{Pb}$ was not detectable.
\end{abstract}

\section{Introduction}

It is well known that the societies in China have been dramatically changing in recent years; the changes involve economy of every family and may affect the nutrition and health of people, especially of children [1-4]. Improved affordability for better foods may contribute favorably in general. Nevertheless, it was also pointed out that economic development may induce nutritionally unfavorable side effects [1]. For example, the trend of obesity among school children and adolescents coincides in time with economic development [3]. Increased intake of processed food due to income growth may cause overweight and even obesity in young people $[2,4]$.

Thus, it is quite conceivable that the records on the nutrient intakes at the beginning of the steady socio-economic development early this century are important as the baseline knowledge to understand the changes in nutrition. Nevertheless, literatures in English on nutrient intakes of children are still scarce to clarify the situation in e.g. early 2000 to 2010.

Data were available to this research group on food intake of 5-6 years-old children in kindergartens in the capital city of Beijing and one provincial capital of Xian for estimation of nutrient intake in 20045. The results will be presented in this article to fill the information gap even in part. Nutrient intakes of adult women in late 1990s have been published previously based on the surveys conducted in Shandong [5], Shaanxi [6], and Jilin provinces [7], China.

\section{Materials and methods}

\section{Survey sites, survey subjects and ethical considerations}

Surveys were conducted in 2004-5 in kindergartens (KGs in short) in the national capital of Beijing and one provincial capital of Xian (Shaanxi province) (for locations, Figure 1).

Correspondence to: Masayuki Ikeda, Apt. 401, Nakanocho 284, Nakachojamachi Shinmachi Nishi-iru, Kamigyo-ku, Kyoto 602-8072, Japan, Tel: 81754518309; Fax: 81754518309; E-mail: m-71-ikeda@nifty.com

Key words: children, China, daily food, kindergarten, nutrient intake, sodium

Received: July 02, 2017; Accepted: July 17, 2017; Published: July 20, 2017 


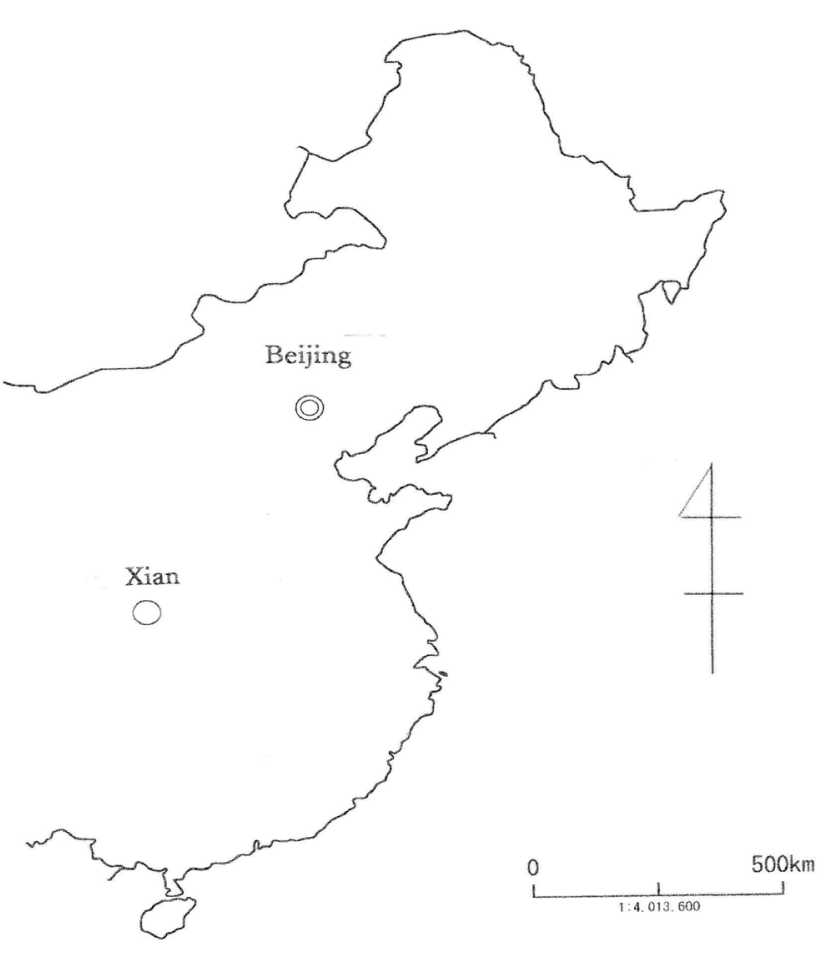

Figure 1. Map of survey site locations in central China

In Beijing, surveys were conducted once in 2004 (to be abbreviated as Beijing 04) and then in 2005 (Beijing 05) at different KGs. The survey in Xian was in 2005. In total, 120 children at the age of 5-6 years [40 children (20 boys and 20 girls) each for Beijing 04, Beijing 05 and Xian] participated in the survey (Table 1). The children were apparently healthy and came to KGs regularly. Guardians (mothers in most cases) provided informed consents (on behalf of the children), offered food duplicate samples (for details, see below), and allowed to measure body sizes of the children.

This survey was conducted in accordance with Declaration of Helsinki, 1947. The study protocol was approved by the Institutional Review Board of Peking University, Beijing, China on 29 $9^{\text {th }}$ March 2004 (the approval number; IRB 00001052-0215).

\section{Collection of food duplicate samples and estimation of nutrient intake}

Each guardian prepared a 24-hour food duplicate sample by collecting foods (including water and drinks) at the exact amounts the child was served on the day [8] following the method previously detailed [6,9-11]. Food items in each duplicate sample were separated manually, and weights were recorded. Then, the food item was coded after China Food Composition Tables (the second edition) [12] by veteran nutritionists who knew local foods well. The nutrient intake was estimated from the code and weight of each food item followed by summation for intake per day [9-13]. The nutritionists estimated the amounts of unmeasurable food items (such as cooking and table salt) to supplement the food intake records [5-7].

Cadmium $(\mathrm{Cd})$ and lead $(\mathrm{Pb})$ in the duplicate samples were measured by inductively coupled plasma-mass spectrometry (ICP-MS) after homogenization and wet-ashing of each sample [11]. Sodium (Na) was measured by flame atomic absorption spectrometry [13] to validate the estimation. Successful quality assurance for the analytical methods employed was also previously described for $\mathrm{Cd}$ and $\mathrm{Pb}$ $[11,13]$.

\section{Statistical analyses}

Because the number of cases studied were limited (see above for the numbers), data for three groups (i.e., Beijing 04, Beijing 05 and Xian) were combined for nutritional evaluation $(n=120)$. Normal distributions were assumed for nutrient intakes so that arithmetic means (AMs) and arithmetic standard deviations (ASDs) were taken as parameters to represent the distribution. $\mathrm{As} \mathrm{Cd}$ and $\mathrm{Pb}$ values are known to distribute log-normally (rather than normally) e.g. [9,14,15], geometric means (GMs) and geometric standard deviations (GSDs) were calculated for these two pollutant elements. For statistical evaluation, $\mathrm{p}<0.05$ was taken as the point of significance.

\section{Results}

\section{Demography of children}

Demographic characteristics of the children are summarized in Table 1 by gender of children.

Calculation with data for Beijing and Xian in combination showed that boys were significantly $(\mathrm{p}<0.05)$ taller and heavier than girls (Table 1). The difference was by $2.2 \mathrm{~cm}$ in height and by $1.2 \mathrm{~kg}$ in weight on an average

\section{Daily dietary intake of energy and nutrients}

On an average, children took $1373 \mathrm{kcal}$ energy, $59.6 \mathrm{~g}$ protein, $39.8 \mathrm{~g}$ lipid, and $204.2 \mathrm{~g}$ carbohydrate per day. Further perusal of the data showed that Beijing children took more energy from rice-based foods $(293 \pm 101 \mathrm{kcal} /$ day as $\mathrm{AM} \pm \mathrm{ASD})$ than from wheat-based foods $(170 \pm 75 \mathrm{kcal} /$ day) $(\mathrm{p}<0.01)$, whereas the reverse was the case for Xian children (i.e., $191 \pm 83 \mathrm{kcal} /$ day from rice and $375 \pm 219 \mathrm{kcal} /$ day from wheat) ( $p<0.01$ for both rice and wheat intake). One child in Xian took no rice and 10 others took $<170 \mathrm{kcal}$ rice /day. These findings suggest that they depended primarily on non-rice cereals (e.g., wheat) as staple foods of the day.

With regard to micro-nutrient intakes (Table 2), of worthy to note was very high $\mathrm{Na}$ intake, i.e., $2250 \mathrm{mg} /$ day. The intake was higher for children in Xian (i.e., $2828 \pm 588 \mathrm{mg} /$ day) than for children in Beijing (i.e., $1961 \pm 472 \mathrm{mg} /$ day) ( $\mathrm{p}<0.01$ for the difference).

\section{Dietary intake of $\mathrm{Cd}$ and $\mathrm{Pb}$}

In Table 3, dietary intake of $\mathrm{Cd}$ and $\mathrm{Pb}$ are presented in terms of GM and GSD. As for locality in heavy metal intake was concerned, Beijing

Table 1. Demography and food intake

\begin{tabular}{|c|c|c|c|c|}
\hline & Height (cm) & BW (kg) & BMI (kg/m²) & $\begin{array}{c}\text { Total food } \\
\text { weight (g/day) }\end{array}$ \\
\hline \multicolumn{5}{|c|}{ Boys } \\
\hline No. of cases & 60 & 60 & 60 & 60 \\
\hline AM & 116.5 & 21.7 & 15.9 & 1703 \\
\hline ASD & 5.3 & 3.7 & 1.8 & 251 \\
\hline \multicolumn{5}{|c|}{ Girls } \\
\hline No. of cases & 60 & 60 & 60 & 60 \\
\hline AM & 114.3 & 20.0 & 15.3 & 1704 \\
\hline ASD & 4.2 & 3.3 & 1.8 & 257 \\
\hline \multicolumn{5}{|c|}{ Boys+Girls } \\
\hline No. of cases & 120 & 120 & 120 & 120 \\
\hline AM & 115.4 & 20.8 & 15.6 & 1703 \\
\hline ASD & 4.9 & 3.6 & 1.8 & 253 \\
\hline
\end{tabular}


Table 2. Dietary intake of energy, macro-nutrients, and selected vitamins and minerals

\begin{tabular}{|c|c|c|c|c|c|c|c|}
\hline \multicolumn{7}{|c|}{ [A] Energy and macro-nutrients } & \\
\hline \multirow{2}{*}{ Parameter } & \multicolumn{3}{|c|}{ Enery from } & \multicolumn{3}{|c|}{ Macro-nutrients } & \\
\hline & Total food & Wheat & Rice & Protein & Lipd & Carbo-hydrate & \\
\hline (Unit/day) & (kcal) & (kcal) & (kcal) & $(g)$ & (g) & (g) & \\
\hline $\mathrm{AM}$ & 1373 & 239 & 259 & 59.6 & 39.8 & 204.2 & \\
\hline ASD & 283 & 170 & 107 & 13.2 & 14.4 & 43.9 & \\
\hline CV $(\%)$ & 20.6 & 71.3 & 41.2 & 22.2 & 36.2 & 21.5 & \\
\hline \multicolumn{7}{|c|}{ [B] Vitamins } & \\
\hline Parameter & Vitamin A & Thiamin & Ribo-flavin & Niacin & Vitamin C & Vitamin E (Total) & \\
\hline (Unit/day) & $\mathrm{RE}(\mu \mathrm{g})$ & (mg) & (mg) & $(\mathrm{mg})$ & (mg) & (mg) & \\
\hline $\mathrm{AM}$ & 779 & 0.7 & 1.1 & 13.5 & 104.9 & 14.7 & \\
\hline ASD & 385 & 0.3 & 0.4 & 3.1 & 44.8 & 5.7 & \\
\hline CV (\%) & 49.4 & 38.4 & 34.9 & 22.8 & 42.8 & 38.5 & \\
\hline \multicolumn{8}{|c|}{ [C] Minerals } \\
\hline Parameter & $\mathrm{Ca}$ & $\mathrm{Fe}$ & $\mathrm{K}$ & $\mathrm{Mg}$ & $\mathrm{Na}$ & $\mathrm{P}$ & $\mathrm{Zn}$ \\
\hline (Unit/day) & $(\mu \mathrm{g})$ & (mg) & (mg) & (mg) & (mg) & (mg) & (mg) \\
\hline $\mathrm{AM}$ & 717 & 19.4 & 1973 & 297 & 2250 & 974 & 8.5 \\
\hline ASD & 286 & 5.6 & 551 & 73 & 656 & 240 & 2.0 \\
\hline CV (\%) & 39.9 & 28.7 & 27.9 & 24.6 & 29.1 & 24.6 & 23.0 \\
\hline
\end{tabular}

Table 3. Daily intake of $\mathrm{Cd}$ and $\mathrm{Pb}$; comparison by survey site

\begin{tabular}{|c|c|c|c|c|}
\hline Survey cite & No. of cases & Parameter & Cd-D $(\boldsymbol{\mu g} / \mathbf{d a y})$ & $\mathbf{P b}-\mathbf{D}(\boldsymbol{\mu g} / \mathbf{d a y})$ \\
\hline \multirow{2}{*}{ Beijing } & \multirow{2}{*}{80} & GM & 10.0 & 11.9 \\
\cline { 3 - 5 } & \multirow{2}{*}{ Xian } & GSD & 1.7 & 1.6 \\
\hline \multirow{2}{*}{ So } & GM & 7.1 & 12.2 \\
\cline { 3 - 5 } & & GSD & 1.3 & 1.7 \\
\hline \multirow{2}{*}{ Significance in difference } & & & $\mathrm{p}<0.01$ & $\mathrm{~ns}$ \\
\hline \multirow{2}{*}{ Total } & \multirow{2}{*}{120} & GM & 8.9 & 12.0 \\
\cline { 3 - 5 } & & GSD & 1.6 & 1.6 \\
\hline
\end{tabular}

Statistical tests were conducted after logarithmic conversion; ns stands for $\mathrm{p} \geqq 0.05$.

and Xian data were presented separately as well as in combination. Comparison between Beijing and Xian showed that children in Xian had less Cd intake than those in Beijing $(\mathrm{p}<0.01)(7.1 \mu \mathrm{g} /$ day for Xian children vs. $10.0 \mu \mathrm{g} /$ day for Beijing children both as GM). Cd intake was $8.9 \mu \mathrm{g} / \mathrm{day}$ when all cases were combined. In case of $\mathrm{Pb}$, the intake for all children in combination was $12.0 \mu \mathrm{g} /$ day with no significant difference ( $\mathrm{p}>0.10)$ between Beijing $(11.9 \mu \mathrm{g} /$ day $)$ and Xian $(12.2 \mu \mathrm{g} /$ day $)$.

\section{Validation of dietary $\mathrm{Na}$ intake}

Accurate assessment of daily $\mathrm{Na}$ intake was considered important because health impact of high $\mathrm{Na}$ intake should be notable as to be discussed later. Thus, $\mathrm{Na}$ intake was evaluated as Food Composition Table [12]-based estimates as supplemented by nutritionists ( $\mathrm{E}$ in short) and also as instrumentally measured values $(M)$. The AM \pm ASD values were $2250 \pm 656 \mathrm{mg} / \mathrm{day}$ for $\mathrm{E}$ and $2117 \pm 516 \mathrm{mg} / \mathrm{day}$ for $\mathrm{M}$. The $\mathrm{E} / \mathrm{M}$ ratio was 1.06 . The $\mathrm{p}$ value was between 0.05 and 0.10 by unpaired t-test and 0.042 by paired t-test. The $\mathrm{M}$ and $\mathrm{E}$ values correlated significantly with each other (Pearson's correlation coefficient $r=0.286$, $\mathrm{p}<0.01, \mathrm{n}=120$ ). Thus, the estimated values were considered to be valid.

\section{Food groups as leading sources for energy, major nutrients, $\mathrm{Ca}$ and $\mathrm{Fe}$}

Food items were classified by food groups. Then, accounts (in percentages) for food groups in contributing energy and macronutrients were calculated (Table 4). Attention was extended to two important micro-nutrient elements of $\mathrm{Ca}$ and $\mathrm{Fe}$.

As it was quite conceivable, cereals were the major source for energy (39.1\%) and carbohydrate (56.9\%). In addition, cereals were the largest source for protein (23.3\%). In contrast, none of animal- based foods of meat (14.9\%), poultries (2.3\%), milks (13.1\%) and eggs (10.5\%) contributed more than $15 \%$ of total protein when evaluated individually, although they accounted for nearly $41 \%$ when combined. Consumption of fish (and shellfish) was very limited (1.8\% on an energy basis) possibly because both Beijing and Xian are inland cities. Rather unexpectedly, pulses such as soy beans contributed less than $10 \%$ each of protein $(8.1 \%)$ and lipid $(6.1 \%)$. Lipid came from animalbased food items $(54.2 \%)$ together with fat and oil used as cooking material (14.9\%). Ca intake was basically from milk $(36.8 \%)$ and vegetables $(20.9 \%)$, whereas cereals and vegetables were the leading sources for Fe (23.8 and 18.6\%, respectively).

It should be worthy to note that the consumption of fast foods (2.3\% on an energy basis) were quite limited both in Beijing $(1.7 \%)$ and Xian (3.5\%). Confectioneries were also consumed only a little (2.6\% on an energy basis).

\section{Analyses for cereal types and accounts for cereals as sources of nutrient minerals}

Four types of cereals were identified in food records, i.e., wheat, rice, maize and millet. Consumption of barley was never detected. With regard to food efficiency, the calculation for the ratio of energy over weight $(\mathrm{kcal} / \mathrm{g})$ gave 1.52 for wheat, 1.60 for rice, 3.10 for maize and 0.46 for millet. The ratio was highest for maize, which was rather contrary to expectation.

The consumption of wheat and rice were common in three survey areas of Beijing 04, Beijing 05 and Xian. As discussed above, Beijing children depended more on rice (58.2\% of total cereals on the energy basis) as compared with $34.1 \%$ on wheat. In contrast, Xian children depended $35.1 \%$ on rice and $60.3 \%$ on wheat. Distribution of maize or millet consumption was limited and quite biased.

The observation that Xian children consumed more wheat-based foods (see above) and ingested more $\mathrm{Na}$ (Table 3) appeared to suggest that the intake of wheat-based foods might be associated with $\mathrm{Na}$ intake (see below for further discussion). Cereals were the major sources for Fe intake but poor sources for Ca (Table 4). In addition, cereals are known to be the major or substantial sources of dietary $\mathrm{Cd}$ and $\mathrm{Pb}$ intake, as to be discussed below. Thus, possible correlation of major cereals (i.e., wheat and rice) with $\mathrm{Na}, \mathrm{Ca}, \mathrm{Fe}, \mathrm{Cd}$ and $\mathrm{Pb}$ intakes were examined. 
Table 4. Contribution of food groups as sources of energy, major nutrients, calcium and iron

\begin{tabular}{|c|c|c|c|c|c|c|c|}
\hline \multirow[b]{2}{*}{ No. } & \multirow[b]{2}{*}{ Food group } & \multicolumn{6}{|c|}{ Contribution (\%) } \\
\hline & & Energy & Protein & Lipid & $\begin{array}{l}\text { Carbo- } \\
\text { hydrate }\end{array}$ & $\mathrm{Ca}$ & $\mathrm{Fe}$ \\
\hline 1 & Cereals & 39.1 & 23.3 & 5.6 & 56.9 & 7.8 & 23.8 \\
\hline 2 & Potatoes and starches & 2.7 & 1.1 & 0.2 & 4.3 & 1.0 & 2.7 \\
\hline 3 & Pulses & 4.6 & 8.1 & 6.1 & 3.3 & 7.7 & 8.3 \\
\hline 4 & Vegetables & 4.3 & 7.1 & 1.6 & 6.0 & 20.9 & 18.6 \\
\hline 5 & Mushrooms and algae & 0.5 & 1.4 & 0.1 & 0.9 & 1.1 & 4.9 \\
\hline 6 & Fruits & 6.3 & 2.2 & 1.0 & 10.4 & 3.0 & 3.7 \\
\hline 7 & Nuts and seeds & 0.8 & 0.6 & 1.7 & 0.4 & 0.5 & 0.4 \\
\hline 8 & Animal meats & 7.6 & 14.9 & 17.6 & 0.5 & 0.6 & 6.6 \\
\hline 9 & Poultries & 1.3 & 2.3 & 3.1 & 0.2 & 0.2 & 0.7 \\
\hline 19 & Milks & 11.0 & 13.1 & 19.0 & 6.2 & 36.8 & 4.4 \\
\hline 11 & Eggs & 5.9 & 10.5 & 14.5 & 0.3 & 4.1 & 6.3 \\
\hline 12 & Fishes and shellfishes & 1.8 & 9.2 & 0.6 & 0.1 & 5.0 & 1.7 \\
\hline 13 & Baby foods & 0.5 & 0.6 & 0.6 & 0.4 & 0.3 & 0.3 \\
\hline 14 & Confectionaries & 2.6 & 1.0 & 3.4 & 2.7 & 0.5 & 1.4 \\
\hline 15 & Fast foods & 2.3 & 1.2 & 2.4 & 2.6 & 0.8 & 0.9 \\
\hline 16 & Beverages & 0.8 & 0.1 & 0.1 & 1.2 & 0.7 & 0.1 \\
\hline 17 & Alcoholic beverages & 0.0 & 0.0 & 0.0 & 0.0 & 0.0 & 0.0 \\
\hline 18 & Sugars and sweetners & 1.4 & 0.1 & 1.3 & 1.9 & 0.5 & 0.4 \\
\hline 19 & Fats and oils & 3.7 & 0.0 & 14.9 & 0.0 & 0.1 & 0.6 \\
\hline 20 & Seasonings & 2.9 & 3.4 & 6.1 & 1.6 & 8.3 & 14.1 \\
\hline 21 & Chinese medicine foods & 0.0 & 0.0 & 0.0 & 0.0 & 0.0 & 0.0 \\
\hline 22 & Others & 0.0 & 0.0 & 0.0 & 0.0 & 0.0 & 0.0 \\
\hline & Total & 100 & 100 & 100 & 100 & 100 & 100 \\
\hline
\end{tabular}

The analyses (Table 5) made it clear that $\mathrm{Na}$ intake was closely $(\mathrm{p}<0.01)$ associated with intake of wheat-based foods (Figure $2 \mathrm{a})$ in contrast to poor association with rice-based foods ( $>0.10$; Figure $2 b$ ). Fe correlated with cereals intake significantly $(\mathrm{p}<0.01)$ whereas $\mathrm{Ca}$ did not show significant correlation $(\mathrm{p}>0.10)$ in agreement with the observation in Table 4 as a poor source for this element.

Cd intake correlated significantly with intakes of total foods, cereals, and rice ( $p<0.01$ for each of the three cases) although not with wheat intake. $\mathrm{Pb}$ intake however did not show significant correlation ( $p>0.10)$ with cereals, rice or wheat intake, although a weak correlation was observed with total food intake (Figure 3 ).

\section{Discussion}

The present survey conducted in 2004-5 disclosed that 120 children at the ages of 5-6 years took $1373 \mathrm{kcal}$ energy and $59.6 \mathrm{~g}$ protein per day on an average (i.e., as AM). The values were lower and higher, respectively, than the values $[1679 \mathrm{kcal}(=7053.1 \mathrm{~J})$ and $51.6 \mathrm{~g}]$ reported by Cui and Dibley [16] for 7-10 years-old children for the year 2004 . The National Survey [17] reporting current situation states that cereals account for $53.1 \%$ on the energy intake basis and the counterpart value from the present survey was $39.1 \%$ (Table 4 ). The account for cereals as a protein source is $47.3 \%$ in the National Survey [17] and $23.3 \%$ in the present survey (Table 4 ). Thus, the values are not unanimous among the reports. The differences might be attributable to the fact that the National Survey [17] covers people of all ages in both urban and rural areas, whereas the present survey was on kindergarten children in the most urbanized areas of Beijing and Xian. In addition, the survey time was different, i.e., the National Survey [17] was in 2015 and the present survey was in 2004-5 with a gap in time of about 10 years. Nevertheless, it appears likely that the nutritional dependency (both for energy and for protein) on cereals was no higher in the past than that at the present time.

Comparisons with AI (adequate intake) and RNI (recommended nutrient intake) values [12] (Table 6) suggest that the protein intake was sufficient but energy intake was barely so (Table 2). Fe intake $(19.4 \mathrm{mg} /$ day on average) was also sufficient. Nevertheless, thiamin $(0.7 \mathrm{mg} /$ day $)$ and Ca intakes $(717 \mu \mathrm{g} /$ day $)$ were either barely sufficient (thiamin) or in short (Ca) (Table 2). Na intake (2250 mg or about 5.6 $\mathrm{g}$ /day as sodium chloride; Table 2) was quite in excess, more than two times recommended AI (900 to $1000 \mathrm{mg}$ ) for 4 or 7 years-old children. The Na intake was even higher for Xian children $(2828 \mathrm{mg} \mathrm{Na}$ or 7.2 g sodium chloride). It should be noted that high salt intake will be an independent factor of obesity [18] in addition to the well-known adverse effect of induction of hypertension later in life [19]. Attention to high salt intake as an etiology of hypertension among aged people has been growing in recent years in China [20-24].

The present survey disclosed that dependency on wheat-based foods as staples was associated with increased $\mathrm{Na}$ intake (Table 5, Figure 2a). To the knowledge of the authors, this observation is the first in reporting the association between wheat-based foods and salt intake in English. No significant effect was observed with intake of ricebased foods. It should be added that this observation is on line with the description in China Food Composition that wheat-based typical Chinese bread (Code Nos. 01-1-404 to 406) contains about $165 \mathrm{mg}$ $\mathrm{Na} / 100 \mathrm{~g}$ [12]. In contrast, $\mathrm{Na}$ contents in cooked rice (Code No. 01 2-402), rice grain (Code Nos. 01-2-101 to 104) and wheat flour (Code Nos. 01-1-201 to 203) are all as low as $<4 \mathrm{mg} / 100 \mathrm{~g}$ [12].

In previous surveys in 1996-1999 on adult women in three urban and rural pairs in Jilin, Shandong, and Shaanxi provinces in China [5-7], energy and $\mathrm{Fe}$ intakes were sufficient in common but clear urban-rural difference was detected in intakes of protein and lipid, as well as $\mathrm{Na}$. Ge [25] also reported better nutritional conditions for urban residents than for villagers in the past. Wang et al. [26], however, observed that urbanrural difference in dietary habits had been gradually disappearing in their 25-year follow-up in Tianjin and its suburbs.

Possibly since 1991, China has been nation-widely conducting Nutrition and Health Surveys once every 2-3 years involving 15 to 20 thousand people at the ages of 7 years and above per occasion [27]. In the survey, data on younger children at pre-school ages were not presented separately, unfortunately. Based on the 1992 data, Ge and Chang [27] concluded that the intakes of vitamin A, thiamin, riboflavin and $\mathrm{Ca}$ did not meet with RNI, and that the problem was most serious in insufficient intake of Ca. Through following-up the data up to 2004, Zhai et al. [28] observed that the problems of low intakes of vitamin $\mathrm{A}$ and $\mathrm{Ca}$ persisted. The same shortages in Ca intake, although not in vitamin $\mathrm{A}$, was detected also in the present analysis (Table 2). With regard to $\mathrm{Ca}$, insufficient dietary $\mathrm{Ca}$ intake may induce unbalance in $\mathrm{Ca}$ metabolism in bones, especially in absence of proper physical exercise [29]. It is well-known that Ca loss is a risk factor for osteoporosis among post-menopausal women [29], although such may not be an issue for children.

Cereals are known to be major dietary sources for two environmental pollutant elements of $\mathrm{Cd}$ and $\mathrm{Pb}[14,15,30-32]$. The present analysis proved that $\mathrm{Cd}$ intake was associated with intakes of cereals, rice in particular, despite the fact that Cd intake in the present survey was as low as $8.9 \mu \mathrm{g} /$ day (Table 3 ), which is only $1.5 \%$ of the levels reported for adult residents in Cd-polluted areas (e.g., 541 or $684 \mu \mathrm{g} /$ day [33]), because foods are exclusive sources of Cd exposure among general populations [14]. The lack of association of $\mathrm{Pb}$ exposure levels with any type of cereals is conceivable, although the level, $12.0 \mu \mathrm{g} /$ day (Table 3) was about $19 \%$ of the levels reported for polluted areas, e.g., $63 \mu \mathrm{g} /$ day [31]. Foods are not always major sources of exposure to $\mathrm{Pb}$, and air-borne $\mathrm{Pb}$ in polluted atmosphere could be a substantial source [15]. 
(a)

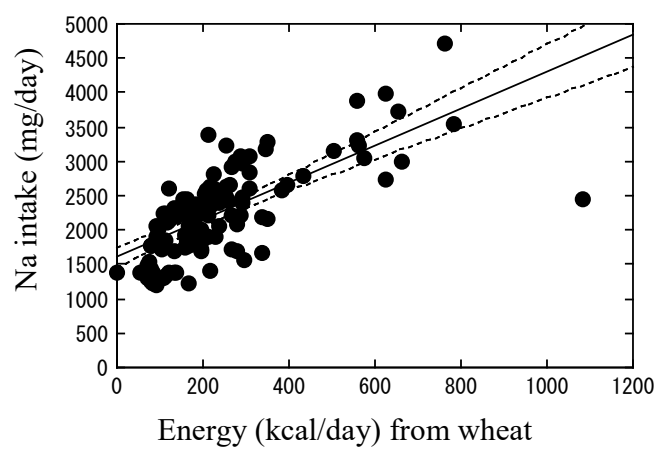

(b)

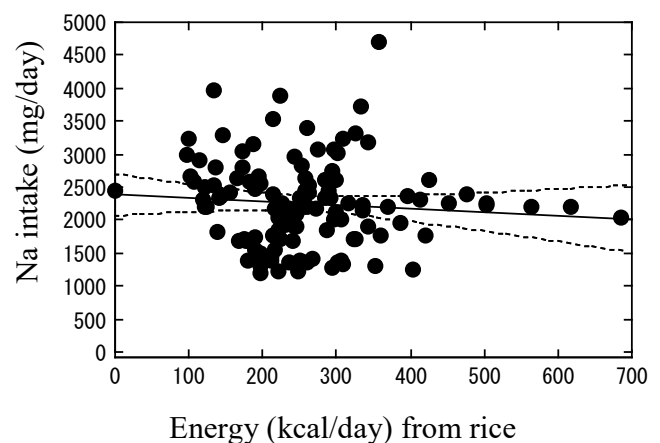

Figure 2. Relation of Na intake with intakes of energy from (a) wheat and (b) rice [The line in the middle is a calculated regression line. Two dotted curves on both sides show $95 \%$ confidence ranges. The equation for the line is; (a) $\mathrm{Y}=-172+0.182 \mathrm{X}(\mathrm{r}=0.703, \mathrm{p}<0.01, \mathrm{n}=120)$, where $\mathrm{X}$ is energy (kcal/day) from wheat, and $\mathrm{Y}$ is Na intake ( $\mathrm{mg} / \mathrm{day})$. (b) $\mathrm{Y}=290-0.014$ $\mathrm{X}(\mathrm{r}=-0.085, \mathrm{p}>0.10, \mathrm{n}=120)$, where $\mathrm{X}$ is energy (kcal/day) from rice, and $\mathrm{Y}$ is Na intake $(\mathrm{mg} /$ day $)$ ].

(a)

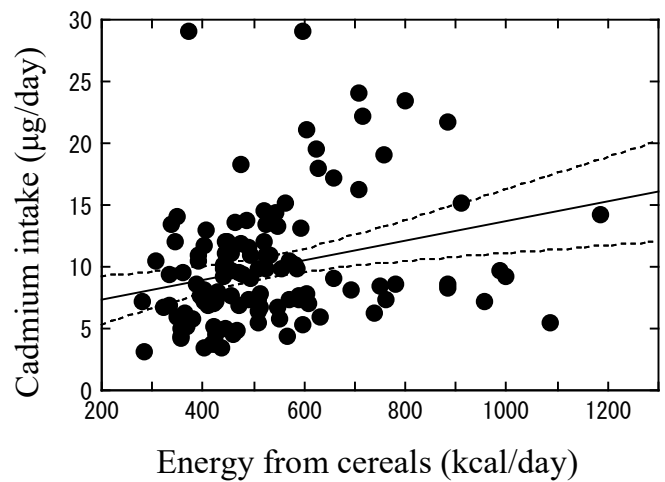

(b)

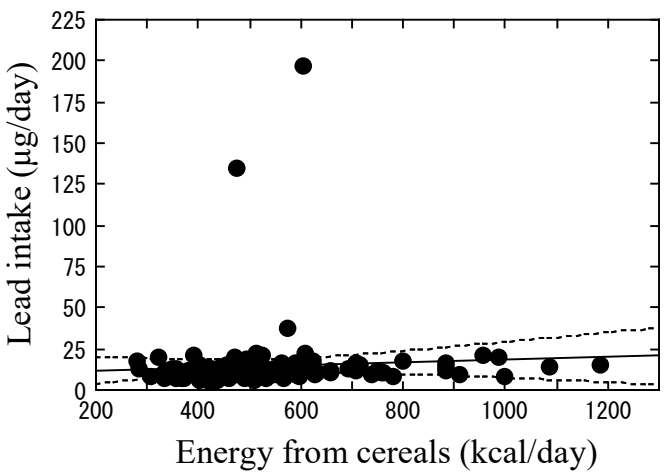

Figure 3. Relation of (a) $\mathrm{Cd}$ and (b) $\mathrm{Pb}$ intakes with cereals intakes [The line in the middle is a calculated regression line. Two dotted lcurves on both sides show $95 \%$ confidence ranges. The equation for the line is; (a) $\mathrm{Y}=440+9.09 \mathrm{X}(\mathrm{r}=0.0 .270, \mathrm{p}<0.01, \mathrm{n}=120)$, where $\mathrm{X}$ is energy $(\mathrm{kcal} /$ day $)$ from cereals, and $\mathrm{Y}$ is $\mathrm{Cd}$ intake $(\mu \mathrm{g} /$ day $)$. (b) $\mathrm{Y}=523+0.521 \mathrm{X}(\mathrm{r}=0.063$, $\mathrm{p}>0.10, \mathrm{n}=120)$, where $\mathrm{X}$ is energy (kcal/day) from cereals, and $\mathrm{Y}$ is $\mathrm{Pb}$ intake $(\mu \mathrm{g} /$ day)].

Table 5. Correlation of nutrient and pollutant elements with energy sources

\begin{tabular}{|c|c|c|c|c|c|c|c|c|c|c|}
\hline \multirow{3}{*}{$\begin{array}{l}\text { Energy intake (kcal/day) } \\
\text { from }\end{array}$} & \multicolumn{6}{|c|}{ Intake of nutrient elements (mg/day) } & \multicolumn{4}{|c|}{ Intake of pollutant elements $(\mu \mathrm{g} /$ day $)$} \\
\hline & \multicolumn{2}{|c|}{$\mathrm{Na}$} & \multicolumn{2}{|c|}{$\mathrm{Ca}$} & \multicolumn{2}{|c|}{$\mathrm{Fe}$} & \multicolumn{2}{|c|}{$\mathrm{Cd}$} & \multicolumn{2}{|c|}{$\mathrm{Pb}$} \\
\hline & $\mathrm{r}$ & $\mathrm{p}$ & $\mathrm{r}$ & $\mathrm{p}$ & $\mathrm{r}$ & $\mathrm{p}$ & $\mathrm{r}$ & $\mathrm{p}$ & $\mathrm{r}$ & $\mathrm{p}$ \\
\hline Total foods & 0.303 & $<0.01$ & 0.707 & $<0.01$ & 0.837 & $<0.01$ & 0.430 & $<0.01$ & 0.202 & $<0.05$ \\
\hline Cereals & 0.563 & $<0.01$ & 0.163 & $>0.10$ & 0.448 & $<0.01$ & 0.269 & $<0.01$ & 0.063 & $>0.10$ \\
\hline Rice & -0.085 & $>0.10$ & 0.381 & $<0.01$ & 0.409 & $<0.01$ & 0.530 & $<0.01$ & 0.023 & $>0 / 10$ \\
\hline Wheat & 0.703 & $<0.01$ & -0.055 & $>0.10$ & 0.155 & $>0.10$ & -0.065 & $>0.10$ & 0.049 & $>0.10$ \\
\hline
\end{tabular}

There are several limitations in the present survey. First of all, the number of cases and sites surveyed was apparently too small. In this sense, the present results should be taken as a case report. Nevertheless, the present survey succeeded to show barely sufficient intake of energy and excess intake of $\mathrm{Na}$, which should be taken as baseline findings. In addition, limited intake of fast foods was also of interest, because the small intake may suggest that food market revolution [4] had not prevailed yet in 2004-5 even in urban areas such as Beijing and Xian. Second point may be the quality of food duplicate samples. The answer to the question if the samples collected really represented daily food consumption depended largely on the honesty of each guardian who prepared the duplicate sample. Sample donors were suggested to avoid over- or under-preparations, but possibilities of such bias could not be excluded. It was not possible to collect food duplicate samples repeatedly for several days. The practice might be too bothering and nerve-taxing for sample donors. Such difficulties should be taken as a problem common to food duplicate-based surveys. In relation to etiology of metabolic syndrome, Xu et al. [34] pointed out gender difference in food habits such that men were prone to take animalbased and fried foods whereas foods for women were energy-rich and more salted. However, such gender-related difference in food habits were not considered in the present analysis because the population surveyed was young children at 5-6 years of age.

\section{Conclusion}

The present analyses on nutrient intakes for children early in this century made it clear that intakes of macro-nutrients such as protein (although cereals-based, primarily) were sufficient even before the social changes in economy took place. With regard to micro-nutrient intakes, problems yet to be solved included insufficient intake of Ca. Very excess intake of Na may be a long-standing yet most urgent problem to be managed for the future health of children. A significant correlation of $\mathrm{Na}$ intake with wheat-based food consumption was detected. 
Table 6. RNI and AI values for nutrients for 5-6 years-old children

\begin{tabular}{|c|c|c|c|c|c|c|c|}
\hline \multicolumn{6}{|c|}{ [A] Energy and macronutrients (Unit) } & & \\
\hline Item Unit & \multicolumn{2}{|c|}{ Energy (kcal) } & \multicolumn{2}{|c|}{ Protein $(g)$} & Fat $(\mathrm{g})$ & & \\
\hline \multirow[t]{2}{*}{ Classification } & \multicolumn{2}{|c|}{ RNI } & \multicolumn{2}{|c|}{ RNI } & & & \\
\hline & Boys & Girls & Boys & Girls & & & \\
\hline 5 years $^{\mathrm{a}}$ & 1600 & 1500 & 55 & 55 & NV & & \\
\hline 6 years $^{\mathrm{a}}$ & 1700 & 1600 & 55 & 55 & NV & & \\
\hline \multicolumn{6}{|c|}{ [B] Vitamins } & & \\
\hline Item & Vit. A & Thiamin & Riboflavin & Niacin & Vit. C & Vit. E (total) & \\
\hline Unit & $\mathrm{RE} \mu \mathrm{g}$ & $\mathrm{mg}$ & $\mathrm{mg}$ & $\mathrm{mg}$ & $\mathrm{mg}$ & $\mathrm{mg}$ & \\
\hline Classification & RNI & RNI & RNI & RNI & RNI & $\mathrm{AI}$ & \\
\hline 4 years $^{\mathrm{a}}$ & 600 & 0.7 & 0.7 & 7 & 70 & 5 & \\
\hline 7 years $^{\mathrm{a}}$ & 700 & 0.9 & 1.0 & 9 & 80 & 7 & \\
\hline \multicolumn{7}{|c|}{ [C] Minerals } & \\
\hline Item & $\mathrm{Ca}$ & $\mathrm{P}$ & $\mathrm{K}$ & $\mathrm{Na}$ & $\mathrm{Mg}$ & $\mathrm{Fe}$ & $\mathrm{Zn}$ \\
\hline Unit & $\mu \mathrm{g}$ & $\mathrm{mg}$ & $\mathrm{mg}$ & $\mathrm{mg}$ & $\mathrm{mg}$ & $\mathrm{mg}$ & $\mathrm{mg}$ \\
\hline Classification & AI & $\mathrm{AI}$ & $\mathrm{AI}$ & $\mathrm{AI}$ & AI & $\mathrm{AI}$ & RNI \\
\hline 4 years $^{\mathrm{a}}$ & 800 & 500 & 1500 & 900 & 150 & 12 & 12.0 \\
\hline 7 years $^{\mathrm{a}}$ & 800 & 700 & 1500 & 1000 & 250 & 12 & 13.5 \\
\hline
\end{tabular}

Values are cited from National Institute of Nutrition and Food Safety, China [12].

$\mathrm{AI}$, adequate intake; NV, no value; RNI, recommended nutrient intake.

${ }^{a}$ Ages of children.

\section{Acknowledgement}

The authors are grateful to children and their guardians for their participation in the survey. Thanks are also due to administrations and staff of the kindergartens for their co-operation. This study was supported in part by grants from the Ministry of Education, Culture, Sports, Science and Technology, Japan: Grant numbers (to T.W.) were 12878013,19500676 and 22500755 for fiscal years of 2000-2002, 20072008 and 2010-2012, respectively.

\section{Conflict of interests}

The authors declare that no conflict of interests exists.

\section{Ethical standards}

This survey was conducted in accordance with Declaration of Helsinki, 1947. The study protocol was approved on 29 March 2004 by the Institutional Review Board of Peking University, Beijing, China (the approval number; IRB 00001052-0215).

\section{Informed consent}

All guardians provided informed consents on behalf of the children.

\section{References}

1. Du S, Mroz TA, Zhai F, Popkin BM (2004) Rapid income growth adversely affects diet quality in China - particularly for the poor. Soc Sci Med 59: 1505-1515. [Crossref]

2. Seo DC, Niu J (2014) Trends in underweight and overweight/obesity prevalence in Chinese youth, 2004-2009. Int J Behav Med 21: 682-690. [Crossref]

3. Zhang J, Seo DC, Kolbe L, Middlestadt S, Zhao W (2010) Trends in overweight among school children and adolescents in seven Chinese Provinces, from 1991-2004. Int $J$ Pediatr Obes 5: 375-382. [Crossref]

4. Zhou Y, Du S, Su C, Zhang B, Wang H, et al. (2015) The food retail revolution in China and its association with diet and health. Food Policy 55: 92-100. [Crossref]

5. Qu JB, Zhang ZW, Xu GF, Song LH, Wang JJ, et al. (1997) Urabn-rural comparison of nutrient intake by adult women in Shandong province, China. Tohoku J Exp Med 183: 21-36.

6. Nakatsuka H, Zhang ZW, Qu JB, Gao WP, Deng YJ, et al. (1999) Urban-rura comparison of nutrient intake by adult women in Shaaanxi province, China. Biomed Environ Sci 12: 270-284. [Crossref]
7. Qu JB, Zhang ZW, Shimbo S, Liu ZM, Cai XC, et al. (2000) Nutrient intake of adult women in Jilin province, China, with special reference to urban-rural differences in nutrition in Chinese continent. Eur J Clin Nutr 54: 741-748.

8. Acheson KJ, Campbell IT, Edholm OG, Miller DS, Stock MJ (1980) The measurement of food and energy intake in man - An evaluation of some techniques. Am J Clin Nut 33: 1147-1154. [Crossref]

9. Ikeda M, Moon CS, Zhang ZW, Iguchi H, Watanabe T, et al. (1995) Urinary a1 microglobulin, B2-microglobulin, and retinol-binding protein levels in general populations in Japan with references to cadmium in urine, blood, and 24-hour food duplicates. Environ Res 70: 35-46.

10. Shimbo S, Watanabe T, Nakatsuka H, Yaginuma-Sakurai K, Ikeda M (2013) Dietary tin intake and association with canned food consumption in Japanese preschool children. Environ Health Preven Med 18: 230-236.

11. Watanabe T, Kim ES, Ko YS, Yang HR, Moon CS, et al. (2015) Food intake survey of kindergarten children in Korea: Part 3 cadmium and lead burden. Environ Health Preven Med 20: 307-313. [Crossref]

12. National Institute of Nutrition and Food Safety, China (Ed) (2009) China Food Composition (2nd edition). Beijing: Peking University Medical Press.

13. Nakatsuka H, Shimbo S, Watanabe T, Yaginuma-Sakurai K, Ikeda M (2013) Applicability of food composition tables as a tool to estimate mineral intake of preschool children in Japan: A validation study. J Trace Elem Med Biol 27: 339-345. [Crossref]

14. Ikeda M, Zhang ZW, Shimbo S, Watanabe T, Nakatsuka H, et al. (2000) Urban population exposure to lead and cadmium in east and south-east Asia. Sci Total Environ 249: $373-384$.

15. Ikeda M, Zhang ZW, Shimbo S, Watanabe T, Nakatsuka H, et al. (2000) Exposure of women in general populations to lead via food and air in East and Southeast Asia. Am J Ind Med 38: 271-280. [Crossref]

16. Cui Z, Dibley MJ (2013) Trends in dietary energy, lipid, carbohydrate and protein intake in Chinese children and adolescents from 1991 to 2009. Br J Nutr 108: 1292 1299.

17. China Center for Disease Control and Prevention (2015) National Nutrition and Chronic Disease Survey China 2015. Beijing: People's Health Publishers.

18. Ma Y, He FJ, MacGregor GA (2015) High salt intake: independent risk factor for obesity? Hypertension 66: 843-849. [Crossref]

9. Institute of Medicine (2004) Dietary Reference Intakes: Potassium, F and others 5 Potassium, and 10 Sodium. Washington DC: National Academies Press: 186-268 and 269-423.

20. Zhao L, Stamler J, Yan LL, Zhou B, Wu Y, et al. (2004) Blood pressure differences between northern and southern Chinese: Role of dietary factors. The international study on macronutrients and blood pressure. Hypertension 43: 1332-1337. [Crossref] 
21. Wu Y, Huxley R, Li L, Anna Y, Xie G, et al. (2008) Prevalence, awareness, treatment and control of hypertension in China. Data from the China National Nutrition and Health Survey 2000. Circulation 118: 2679-2686.

22. Li N, Yan LL, Niu W, Labarthe D, Feng X, et al. (2013) A large-scale cluster randomized trial to determine the effects of community-based dietary sodium reduction - The China rural health initiative sodium reduction study. Am Heart $J$ 166: 815-822. [Crossref]

23. Chu C, Cao Y, Mu J (2016) $\mathrm{CHl} 02-3$ evidence and initiatives in the dietary salt reduction in China. J Hypertens 34 Suppl 1 - ISH 2016 Abstract Book: e201. [Crossref]

24. Yu D, He Y, Fang H, Xu X, Wang X, et al. (2016) Salt intake among Chinese adults in 2010-2012. Zhonghua Yu Fang Yi Xue Za Zhi 50: 217-220. [Crossref]

25. Ge K (1995) Dietary pattern and physical development in China - based on the 1992 national nutrition survey. Asia Pac J Clin Nutr 4 Suppl 1: 19-23. [Crossref]

26. Wang X, Wu Y, Zhang X, Zhang M, Huang G (2016) Dietary changes over 25 years in Tianjin residents: Findings from the 1986-1988, 2000-2004, and 2008-2011 nutrition survey. Nutrients 8: 62. [Crossref]

27. Ge KY, Chang SY (2001) Dietary intake of some essential micronutrients in China. Biomed Environ Sci 14: 318-324. [Crossref]
28. Zhai F, Wang H, Du S, He Y, Wang Z, et al. (2007) Lifespan nutrition and changing socio-economic conditions in China. Asia Pac J Clin Nutr 16(1): 374-382. [Crossref]

29. Institute of Medicine (1997) Dietary Reference Intakes: Calcium, Phosphorus, Magnesium, Vitamin D, and Fluoride. 4 Calcium. Washington DC: National Academies Press, pp: 71-145.

30. Chen F, Cole P, Wen L, Mi Z, Trapido EJ (1994) Estimates of trace element intakes in Chinese farmers. J Nutr 124: 196-201. [Crossref]

31. Sun JF, Wang CN, Wu YN, Yuan BJ, Tian ZH, et al. (2011) Long-term dietary exposure to lead of the population of Jiangsu Province, China. Food Add Contam Pt A 28: 107-114. [Crossref]

32. Jin Y, Liu P, Wu Y, Min J, Wang C, et al. (2014) A systematic review on food lead concentration and dietary lead exposure in China. Chin Med J (Engl) 127: 2844-2849. [Crossref]

33. Jin T, Kong Q, Ye T, Wu X, Nordberg GF (2004) Renal dysfunction of cadmiumexposed workers residing in a cadmium-polluted environment. Bio Metals 17: 513-518.

34. Xu SH, Qiao B, Huang JJ, Sun CM, Cui Y, et al. (2016) Gender difference in dietary patterns and their association with prevalence of metabolic syndrome among Chinese: A cross-sectional study. Nutrients 8: 180. [Crossref]

Copyright: (C2017 Nakatsuka H. This is an open-access article distributed under the terms of the Creative Commons Attribution License, which permits unrestricted use, distribution, and reproduction in any medium, provided the original author and source are credited. 